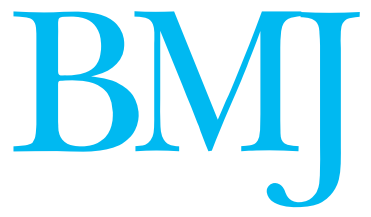

\title{
Stem cell therapy: hope or hype?
}

\author{
Safety and quality must be assured before this treatment can really benefit patients
}

$\mathrm{T}$ he use of human embryonic stem cells has been hailed as the next major step in the battle against serious degenerative disorders, such as diabetes and heart disease, and for some debilitating or lethal neurological diseases, such as Parkinson's and motor neurone disease. News reports and promotional material on websites often convey the impression that this therapy is safe and immediately or imminently available. Whether this is just hype, and how much hope patients should invest in this technology, are issues being discussed at a public debate in London this week. ${ }^{\mathrm{w}}$

Although the number of human embryonic stem cell lines has increased considerably in the past two years, few of these have been well characterised, and large hurdles still need to be overcome to ensure safety and efficacy. ${ }^{1}$ These will require substantial further investment and research. Stem cells have not yet been grown in the conditions that would be expected for any pharmaceutical product destined for use in vivo. ${ }^{2}$ Even the embryos from which human embryonic stem cells could be derived are still cultured in vitro in the presence of human or animal products. The premature use of cell therapy could put many patients at risk of viral or prion diseases unless systems are in place for the appropriate selection and screening of donors and for quality assurance.

The lessons of the premature application of gene therapy, the devastation caused by HIV transmission to people with haemophilia, the clinical and legal ${ }^{\mathrm{w} 2}$ problems resulting from hepatitis $\mathrm{C}$ infection through blood transfusion, and the crisis caused by bovine spongiform encephalopathy ${ }^{\mathrm{w} 3}$ should all be learning opportunities. Expansion of stem cell cultures could allow a single stem cell line to be used for many hundreds, if not thousands of patients, exponentially amplifying the potential risk of disease transmission from a single infected donor. Transmission of malignant, autoimmune, and infectious diseases by organs, tissues, and cells are rare but well documented events. ${ }^{w 4 w^{5}}$ Tissues have transmitted prions, ${ }^{3}$ and the prion that causes variant Creutzfeldt-Jakob disease (vCJD) has almost certainly been transmitted by blood transfusion. ${ }^{45}$ No blood test for vCJD currently exists, and neither does an effective method of inactivating the causative agent.

Change is on the way, however. Although those working with stem cells in the United Kingdom have non-statutory guidance in the form of a code of prac- mandatory for them to comply with the EU directive on tissues and cells. ${ }^{7}$ Thus all laboratories for in vitro fertilisation and laboratories for producing cell lines with therapeutic intent will have to conform to a new standard of quality even more stringent than the current requirements of the Human Fertilisation and Embryology Authority (HFEA).

The EU directive will cover selection of donors, testing, and procurement of the starting material for cell lines, tracking cells from donor to recipient, use of a specified coding system, and reporting of adverse events. The source of all material will have to be traceable even if it is anonymised at the point of production. A policy collaborative group convened by the English Department of Health, working over two years, enabled key stakeholders from across the United Kingdom to develop guidance to support local implementation of the directive: this guidance will be issued this summer. Furthermore, the Medical Research Council has awarded grants to five units performing in vitro in the United Kingdom to help achieve rigorous standards for the production of therapeutic grade embryonic stem cells.

Potential donors of blood components and blood products are required to give their medical and behavioural histories, and blood samples are tested rigorously at the time of each donation to minimise risk. A novel approach to safety could be used for stem cell lines. Since these lines are potentially immortal and infinitely expandable, it would therefore be possible to test the cell line itself rather than surrogate samples from couples at the time of donation. Clearly, existing tests for viruses or prions would have to be validated in this context before using stem cell lines as the main test analytes.

The drive to be the first to provide cell lines for therapy could compromise safety for recipients and could lead this technology into the realms of quackery. Such fears are already being realised in India ${ }^{8}$ and Russia, ${ }^{9}$ where intervention by the governments may be needed to limit or prevent the escalating numbers of clinics offering stem cell cures for all sorts of ills. Despite inadequate preliminary data on clinical safety or from animal experiments, trials using cells derived from autologous bone marrow samples are already being conducted on patients with heart disease,$^{10}$ with urgency and therapeutic need being cited as the

Additional references w1-w5 are on bmj.com 
reasons for immediate implementation. However, urgency is not an excuse for bad science. Animal experiments should be conducted to understand further the host destination and integration of transplanted cells, and the risks of neoplasia arising in cells implanted into new environments. ${ }^{1}$ The ethics of transferring human stem cells into animal hosts in order to develop new therapies for debilitating disorders must be considered as part of the wider stem cell ethical debate. ${ }^{11}$

Commercial companies are springing up around the world with all the fervour of a new "biological dotcom" era, but with selective memory loss for the fact that unrealistically high expectations burst that bubble. We can only hope that any corporate failure to make immediate financial success out of stem cell research does not drag down a promising technology. Stem cell therapy needs to be nurtured safely and methodically to provide real benefit to patients in the future.

Peter Braude professor of obstetrics and gynaecology (obgyn@kcl.ac.uk)

Stephen L Minger director of stem cell biology laboratory Stem Cell Group, Division of Reproductive Health, Endocrinology and Development, Guy's Campus, King's College London SE1 9RT

Ruth M Warwick consultant haematologist

Tissue Services, National Blood Service, Edgware HA8 9BD

Competing interests: PB and SLM are recipients of Medical Research Council grants for human stem cell derivation, and SLM has participated in visits sponsored by the Department of Trade and Industry to stem cell labs in the United States and the far east. PB will be speaking at this week's public debate in London, "Stem Cell Research: Hope or Hype?" but will not receive a fee.

1 Select Committee of the House of Lords. Stem cell research-report. Select Committee of the House of Lords. Stem cell research-report.
London: Stationery Office, 2002. www.parliament.the-stationeryLondon: Stationery Office, 2002. www.parliament.the-stationery-
office.co.uk/pa/ld200102/ldselect/ldstem/83/8301.htm (accessed 13 May 2005)

2 Medicines and Healthcare products Regulatory Agency. Rules and guidance for pharmaceutical manufacturers and distributors. London: Department of Health, 1997. http://medicines.mhra.gov.uk/inforesources/ publications/orangeguide.htm (accessed 13 May 2005).

3 Centers for Disease Control and Prevention. Creutzfeldt-Jakob disease in patients who received a cadaveric dura mater graft-Spain 1985-1992. Morb Mortal Wkly Rep MMWR 1993:42:560-3. http://www.cdcoov/ $\mathrm{mmwr} / \mathrm{preview} / \mathrm{mmwrhtml} / 00021225$.htm

4 Lewrelyn CA, Hewitt PE, Knight RS, Amar K, Cousens S, Maken J et al. Possible transmission of variant Creutzfeldt-Jakob disease by blood transfusion. Lancet 2004;363:417-21.

5 Pransfusion. Lancet 2004;363:417-21. after blood transfusion in a PRNP codon 129 heterozygous patient. Lancet 2004;364:527-9.

6 Department of Health. A code of practice for tissue banks providing tissues of human origin for therapeutic purposes. 2001. www.dh.gov.uk/Publications AndStatistics/Publications/PublicationsPolicyAndGuidance/Publications PolicyAndGuidanceArticle/fs/en?CONTENT_II $=4006116 \& \mathrm{chk}=8 \mathrm{VQ}$ R $\% 2 B 5$

7 Directive 2004/23/EC of the European Communities and of the Council of 31 March 2004 on setting standards of quality and safety for the donation, procurement, testing, processing, preservation, storage and donation, procurement, testing, processing, preservation, storage and
distribution of human tissues and cells. Official J Eur Union 2004. http:// distribution of human tissues and cells. Official J Eur Union 2004. http://
europa.eu.int/eur-lex/pri/en/oj/dat/2004/__102/_10220040407en00 480058.pdf (accessed 13 May 2005).

8 Jayarama KS. Indian regulations fail to monitor growing stem-cell use in clinics. Nature 2005, March 17:434, 259

9 Danilova, M. Stem cell craze spreads in Russia. Associated Press: http://apnews.myway.com/article/20050314/D88QNPG80.html

10 Schachinger V, Assmus B, Britten MB, Honold J, Lehmann R, Teupe C, et al. Transplantation of progenitor cells and regeneration enhancement in al. Transplantation of progenitor cells and regeneration enhancement in Trial. J Am Coll Cardiol 2004;44:1690-9.

11 Rifkin J. Are you a man or a mouse? Guardian 2004, 15 March.

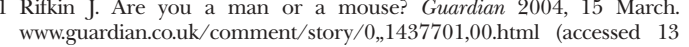
May 2005)

\section{Aid after disasters}

\section{Needs a long term public mental health perspective}

$\mathrm{T}$ The crisis caused by the earthquake and tsunami in South East Asia six months ago elicited an unprecedented aid response by humanitarian agencies financed by numerous governments and private citizens. With communicable disease more or less under control, aid agencies now focus increasingly on the mental suffering of surviving populations. We estimate here the likely mental health and psychosocial support needs of those affected and provide a public health framework for long term assistance.

Although no reliable data exist on numbers of people with problems related to mental health in countries affected by the tsunami, the estimated rates described in the table give a rough picture at the population level of what may be expected. Observed prevalence rates will vary with case definition, method of assessment, time since the disaster, and community. Across and within countries, communities differ in current and previous disaster exposure and in sociocultural factors that may influence social support, coping, and readiness to endorse symptoms in surveys. Disaster affected populations comprise people with non-pathological mild psychological distress that resolves in a few days or weeks; people with non-pathological moderate or severe psychological distress that may resolve over time or with mild distress that becomes chronic; and people with mental disorders such as psychosis, severe depression, and severely disabling presentations of an anxiety disorder (see table on bmj.com).

That post-traumatic stress disorder is the main or most important mental disorder resulting from disaster is a misconception. It is only one of a range of often comorbid common mental disorders (such as mood and anxiety disorders) that tend to make up the mild and moderate mental disorders and which become more prevalent after disaster. ${ }^{1}$ The low level of help seeking behaviour for post-traumatic stress disorder in many non-Western cultures implies that it is not the focus of many survivors of trauma. ${ }^{23}$ WHO is concerned that some groups are directing disproportional resources to clinical care focused on posttraumatic stress disorder. WHO argues for a public health perspective that considers all mental problems, ranging from pre-existing severe mental disorder to widespread non-pathological psychological distress induced by trauma and loss. ${ }^{4}$

See table on bmj.com
Clinical review p 1199 